\title{
Tenacibaculum soleae sp. nov., isolated from diseased sole (Solea senegalensis Kaup)
}

Correspondence Ysabel Santos ysantos@usc.es

\author{
Maximino Piñeiro-Vidal, ${ }^{1}$ Cristina G. Carballas, ${ }^{1}$ Oscar Gómez-Barreiro, ${ }^{2}$ \\ Ana Riaza ${ }^{2}$ and Ysabel Santos $^{1}$
}

${ }^{1}$ Departamento de Microbiología y Parasitología, Edificio CIBUS, Facultad de Biología, Universidad de Santiago de Compostela, Campus Sur, 15782 Santiago de Compostela, Spain

${ }^{2}$ Stoltseafarm S.A., Lira, Spain

\begin{abstract}
A novel Gram-negative, rod-shaped, gliding bacterial strain designated LL04 12.1.7 ${ }^{\top}$ was isolated from diseased sole (Solea senegalensis Kaup) in Galicia, Spain. Colonies were yellow-pigmented with uneven edges and did not adhere to the agar. The DNA G+C content of the strain was 29.8 mol\%. 16S rRNA gene sequence similarity analysis indicated that strain LL04 $12.1 .7^{\top}$ is a member of the genus Tenacibaculum in the family Flavobacteriaceae. Sequence similarities between the isolate and the type strains of other members of the genus were $96.7-94.8 \%$. The major fatty acids (>10\% of total fatty acids) were iso- $\mathrm{C}_{15: 0}(23.1 \%)$, iso- $\mathrm{C}_{15: 0} 3-\mathrm{OH}(10.6 \%)$, $\mathrm{C}_{15: 1} \omega 6 c(12.2 \%)$ and summed feature 3 (comprising $\mathrm{C}_{16: 1} \omega 7 c$ and/or iso- $\mathrm{C}_{15: 0} 2-\mathrm{OH}$, 11.0\%). Genotypic and phenotypic data distinguished strain LL04 12.1.7 from the 11 recognized Tenacibaculum species, indicating that it represents a novel species, for which the name Tenacibaculum soleae sp. nov. is proposed. The type strain is strain LL04 12.1.7 ${ }^{\top}$ (=CECT $7292^{\top}=$ NCIMB $14368^{\top}$ ).
\end{abstract}

The genus Tenacibaculum (Suzuki et al., 2001) in the family Flavobacteriaceae (Reichenbach, 1992a, b; Bernardet et al., 1996, 2002) currently comprises 11 species derived from different marine ecosystems and intensive aquaculture systems. Tenacibaculum maritimum and Tenacibaculum discolor were isolated from diseased fish (Wakabayashi et al., 1986; Piñeiro-Vidal et al., 2008); Tenacibaculum ovolyticum was isolated from fish eggs (Hansen et al., 1992); Tenacibaculum litopenaei (Sheu et al., 2007) and Tenacibaculum gallaicum (Piñeiro-Vidal et al., 2008) were from seawater of shrimp- and turbot-holding tanks, respectively; Tenacibaculum amylolyticum and Tenacibaculum mesophilum were from marine macroalgae and sponge, respectively (Suzuki et al., 2001); Tenacibaculum skagerrakense was from seawater (Frette et al., 2004); and Tenacibaculum lutimaris (Yoon et al., 2005), Tenacibaculum litoreum (Choi et al., 2006) and Tenacibaculum aestuarii (Jung et al., 2006) were from tidal flat sediment.

During the characterization of bacteria isolated from a diseased cultured sole (Solea senegalensis Kaup), strain LL04 12.1.7 ${ }^{\mathrm{T}}$ was recovered on plates of Flexibacter maritimus medium (FMM) (Pazos et al., 1996). Subcultivation was done on FMM or marine agar 2216 (MA; Difco) at $25{ }^{\circ} \mathrm{C}$ for $48 \mathrm{~h}$. Strains were preserved at

The GenBank/EMBL/DDBJ accession number for the 16S rRNA gene sequence of strain LLO4 $12.1 .7^{\top}$ is AM746476.
$-80{ }^{\circ} \mathrm{C}$ in both marine broth 2216 (MB; Difco) supplemented with $15 \%(\mathrm{v} / \mathrm{v})$ glycerol and Microbank tubes (Prolab Diagnostics). Experimental infection assays have demonstrated that strain LL04 $12.1 .7^{\mathrm{T}}$ is virulent for fingerlings of sole and turbot, but not for mice (data not shown).

Morphological, physiological and biochemical tests were performed as described by Bernardet et al. (2002). The Gram reaction was tested by using the bioMérieux Gram stain kit according to the manufacturer's instructions and the non-staining $\mathrm{KOH}$ method (Buck, 1982). Gliding motility was determined by phase-contrast microscopic examination of a fresh $\mathrm{MB}$ culture by the hanging drop technique as recommended by Bernardet et al. (2002). The presence of flexirubin-type pigments was determined by using the $\mathrm{KOH}$ test as described by Reichenbach (1989). Catalase and oxidase activities were determined as described by Cowan \& Steel (1965). The capacity of the strain to grow under anaerobic conditions was tested on MA using the GasPak anaerobic system (BBL). The optimal $\mathrm{pH}$ and the $\mathrm{pH}$ range for growth were determined in FMM broth adjusted to $\mathrm{pH} 4-10$ according to Suzuki et al. (2001). Growth at various temperatures $(8,15,18,22,25$, 30,37 and $44{ }^{\circ} \mathrm{C}$ ) was determined on FMM agar plates. Tolerance to salinity was tested in FMM broth containing $10,20,30,50,70$ or $100 \%$ seawater or $0.8,1,3,5,7$ or $10 \%$ (w/v) $\mathrm{NaCl}$. Indole and $\mathrm{H}_{2} \mathrm{~S}$ production were tested on FMM broth supplemented with $1 \%(\mathrm{w} / \mathrm{v})$ tryptone or $5 \%$ 
(w/v) peptone, respectively. The Voges-Proskauer reaction was evaluated in seawater with $0.7 \%(\mathrm{w} / \mathrm{v})$ peptone and $0.5 \%(\mathrm{w} / \mathrm{v})(+)$-D-glucose. The capacity of the strain to degrade casein $(1 \%)$, gelatin $(1 \%)$, starch $(1 \%)$ and Tween 80 (1\%) was evaluated in FMM medium (Suzuki et al., 2001). Utilization of carbon sources was tested on basal agar medium $\left(0.2 \mathrm{~g} \mathrm{NaNO}_{3}, 0.2 \mathrm{~g} \mathrm{NH}_{4} \mathrm{Cl}, 0.05 \mathrm{~g}\right.$ yeast extract and $15 \mathrm{~g}$ agar in 11 artificial seawater) containing $0.4 \%$ carbon source [sucrose, (-)-D-ribose, $(+)$-D-galactose, $(+)$-D-glucose, L-proline, L-glutamate or L-tyrosine] as described by Suzuki et al. (2001). The absence of growth after 1 month of incubation was scored as a negative result. Other enzyme activities were evaluated in the API ZYM system (bioMérieux) following the manufacturer's instructions, except that sterile seawater was used as the suspension medium.

For analysis of fatty acid methyl esters, strain LL04 12.1.7 was grown on MA plates for $48 \mathrm{~h}$ at $25{ }^{\circ} \mathrm{C}$. Cell harvesting, saponification of lipids, methylation of fatty acids, extraction of fatty acid methyl esters, washing of extracts and GC analysis were performed according the standardized procedures of the Microbial Identification system (MIDI; Microbial ID) (Sasser, 1990).

Determination of the DNA G $+\mathrm{C}$ content and sequencing of the 16S rRNA gene of the isolate were carried out by the identification service of the DSMZ, Braunschweig, Germany. The 1506 bp sequence of strain LL04 12.1.7 was automatically aligned using CLUSTAL W (Thompson et al., 1994) with those of the type strains of the 11 Tenacibaculum species and of other representative members of the family Flavobacteriaceae obtained from GenBank/EMBL. Phylogenetic trees were constructed by the neighbour-joining (Saitou \& Nei, 1987) and maximum-parsimony (Fitch, 1971) methods (Fig. 1). The evolutionary distance matrix for the neighbour-joining method was generated according to Kimura's two-parameter model (Kimura, 1980). To evaluate phylogenetic trees, a bootstrap analysis with 1000 sample replications was performed with the SEQBOOT and CONSENSE programs in the PHYLIP 3.67 package (Felsenstein, 2007). The identification of phylogenetic neighbours and calculation of pairwise $16 \mathrm{~S}$ rRNA gene sequence similarity were achieved using the EzTaxon server (http://www.eztaxon.org/; Chun et al., 2007). Results of morphological, physiological and biochemical tests are given in Table 1 and in the species description.

Fatty acid composition data for strain LL04 $12.1 .7^{\mathrm{T}}$ and type strains of other Tenacibaculum species are detailed in Table 2. The main difference between the novel isolate and the other Tenacibaculum type strains was the high content of unsaturated fatty acids (13.9\%) in strain LL04 12.1.7 ${ }^{\mathrm{T}}$. The cellular fatty acid profile of strain LL04 $12.1 .7^{\mathrm{T}}$ was dominated by iso- $\mathrm{C}_{15: 0}(23.1 \%)$, iso- $\mathrm{C}_{15: 0} 3-\mathrm{OH}(10.6 \%)$, iso- $\mathrm{C}_{16: 0} 3-\mathrm{OH}(8.4 \%), \mathrm{C}_{15: 1} 1 \omega 6 c(12.2 \%)$ and summed feature 3 (comprising $\mathrm{C}_{16: 1} \omega 7 c$ and/or iso- $\mathrm{C}_{15: 0}$ 2-OH; $11.0 \%$ ) (Table 2).

The DNA G $+\mathrm{C}$ content of strain LL04 12.1.7 ${ }^{\mathrm{T}}$ was $29.8 \mathrm{~mol} \%$, the lowest reported value within the genus Tenacibaculum. Comparison of the $16 \mathrm{~S}$ rRNA gene sequence of strain LL04 12.1.7 ${ }^{\mathrm{T}}$ with those of the type strains of the 11 Tenacibaculum species and other members of the family Flavobacteriaceae demonstrated that strain LL04 12.1.7 formed a robust cluster with the Tenacibaculum species. The phylogenetic tree based on 16S rRNA gene sequences is shown in Fig. 1. The closest relatives of strain LL04 12.1.7 were the type strains of $T$. ovolyticum and $T$. aestuarii (96.7\% sequence similarity), T. lutimaris and T. mesophilum (96.4\%), T. gallaicum (96.2\%), T. amylolyticum (96.0\%), T. litoreum (95.9\%), T. discolor (95.8\%), T. skagerrakense (95.7\%), T. litopenaei (95.0\%) and T. maritimum (94.8\%). All these values are lower than the theoretical threshold (97\%) for the delineation of bacterial species based on $16 \mathrm{~S}$ rRNA gene sequence similarity (Stackebrandt \& Goebel, 1994; Stackebrandt \& Ebers, 2006). According to the phenotypic and genetic data obtained in this study, it is concluded that strain LL04 12.1.7 ${ }^{\mathrm{T}}$ represents a novel species within the genus Tenacibaculum, for which the name Tenacibaculum soleae sp. nov. is proposed.

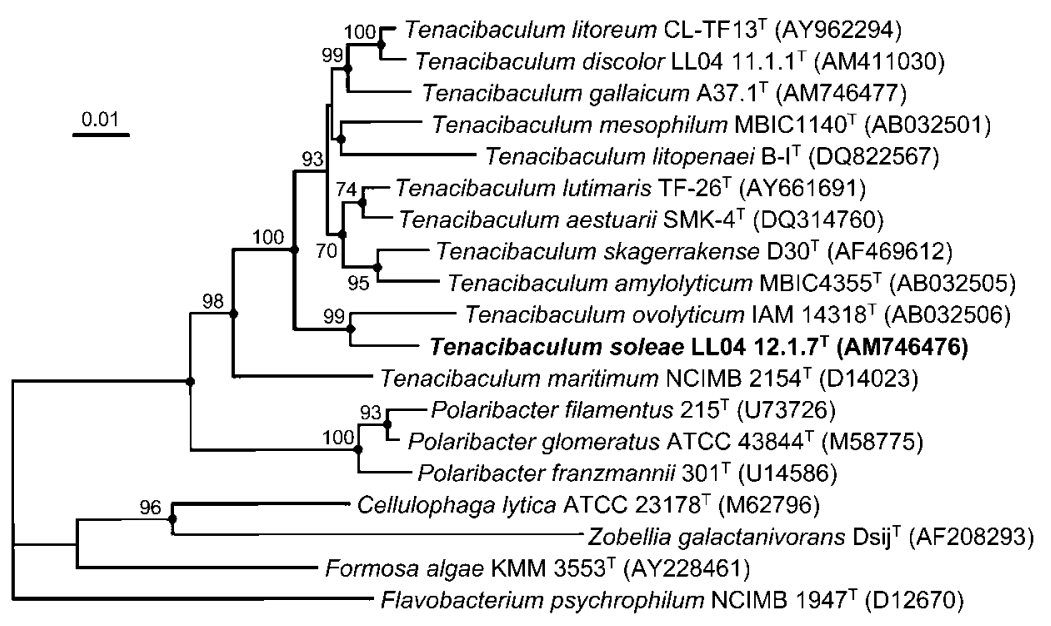

Fig. 1. Neighbour-joining phylogenetic tree based on 16S rRNA gene sequences showing relationships between strain LL04 12.1.7 ${ }^{\top}$, other members of the genus Tenacibaculum and related genera of the family Flavobacteriaceae. Bootstrap values $>50 \%$ (based on 1000 replications) are shown at branching points. Solid circles indicate that the corresponding nodes are also recovered in the maximum-parsimony tree. Bar, 0.01 substitutions per site. 
Table 1. Differential phenotypic characteristics of strain LLO4 $12.1 .7^{\top}$ and the type strains of other Tenacibaculum species

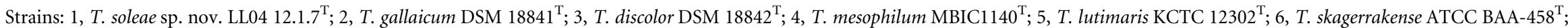

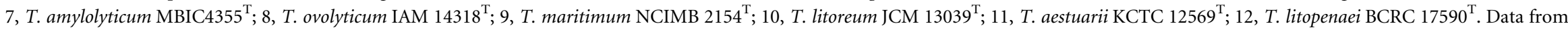

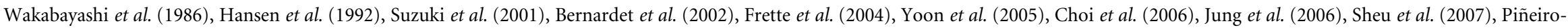
Vidal et al. (2008) and this study. +, Positive; -, negative; W, weakly positive; ND, no data available; NG, no growth.

\begin{tabular}{|c|c|c|c|c|c|c|c|c|c|c|c|c|}
\hline Character & 1 & 2 & 3 & 4 & 5 & 6 & 7 & 8 & 9 & 10 & 11 & 12 \\
\hline Colour & Yellow & Bright yellow & Bright yellow & Yellow & Pale yellow & Bright yellow & Yellow & Pale yellow & Pale yellow & Pale yellow & Pale yellow & Yellow \\
\hline Cell size $(\mu \mathrm{m})$ & $2-25 \times 0.5$ & $2-30 \times 0.5$ & $2-30 \times 0.5$ & $1.5-10 \times 0.5$ & $2-10 \times 0.5$ & $2-15 \times 0.5$ & $2-5 \times 0.4$ & $1.5-10 \times 0.5$ & $2-30 \times 0.5$ & $2-35 \times 0.3-0.5$ & $2-3.5 \times 0.3$ & $2-10 \times 0.3-0.5$ \\
\hline $\begin{array}{l}\text { Spherical cells in } \\
\text { stationary phase }\end{array}$ & Frequent & Rare & Rare & Very rare & Very rare & Frequent & Very rare & $\mathrm{ND}$ & Frequent & Very rare & Very rare & Very rare \\
\hline Gliding motility & + & + & + & + & + & - & + & + & + & + & + & + \\
\hline \multicolumn{13}{|l|}{ Growth with: } \\
\hline $\mathrm{NaCl}(\%)$ & NG & NG & NG & $1-7$ & $<8(2-3)$ & NG & 3 & NG & NG & $3-5$ & $2-3$ & $2-10$ \\
\hline Seawater $(\%)$ & $55-100$ & $30-100$ & $30-100$ & $10-100$ & $25-175$ & $25-150$ & $50-100$ & $70-100$ & $30-100$ & $25-250$ & ND & ND \\
\hline Temperature range $\left({ }^{\circ} \mathrm{C}\right)$ & $14-30$ & $14-38$ & $14-38$ & $15-40$ & $10-39$ & $10-40$ & $20-35$ & $4-25$ & $15-34$ & $5-40$ & $9-41$ & ND \\
\hline $\begin{array}{l}\text { Optimal growth } \\
\text { temperature }\left({ }^{\circ} \mathrm{C}\right)\end{array}$ & $22-25$ & $25-30$ & $25-30$ & $28-35$ & $30-37$ & $25-37$ & $27-30$ & ND & $25-30$ & $35-40$ & $30-37$ & $28-37$ \\
\hline $\mathrm{pH}$ range & $6.0-8.0$ & $6.0-8.0$ & $6.0-8.0$ & $5.3-9$ & $7-8$ & $6-9$ & $5.3-8.3$ & $5.9-8.6$ & $5.9-8.6$ & $6.0-10.0$ & $5.5-8.5$ & $7.0-8.0$ \\
\hline \multicolumn{13}{|l|}{ Degradation of: } \\
\hline Gelatin & + & + & + & - & + & + & - & - & + & - & + & + \\
\hline Starch & - & - & - & + & - & + & + & + & + & + & - & + \\
\hline Tween 80 & - & - & - & - & - & - & + & + & + & + & + & - \\
\hline \multicolumn{13}{|l|}{ Carbon source utilization } \\
\hline (+)-D-Galactose & - & - & - & $\mathrm{ND}$ & ND & - & $\mathrm{ND}$ & $\mathrm{ND}$ & - & - & ND & ND \\
\hline (+)-D-Glucose & - & - & - & $\mathrm{ND}$ & - & + & $\mathrm{ND}$ & $\mathrm{ND}$ & - & - & - & + \\
\hline L-Proline & - & + & + & + & - & + & + & - & - & + & - & + \\
\hline L-Glutamate & - & + & + & + & - & + & + & - & $\mathrm{w}$ & - & - & + \\
\hline L-Tyrosine & - & - & - & $\mathrm{ND}$ & ND & $\mathrm{ND}$ & ND & ND & - & ND & ND & ND \\
\hline \multicolumn{13}{|l|}{ API ZYM results } \\
\hline Esterase lipase (C8) & + & + & + & ND & ND & $\mathrm{ND}$ & $\mathrm{ND}$ & $\mathrm{ND}$ & + & - & + & + \\
\hline Trypsin & - & + & + & ND & ND & ND & ND & ND & + & + & - & - \\
\hline$\alpha$-Chymotrypsin & - & + & + & ND & $\mathrm{ND}$ & $\mathrm{ND}$ & ND & $\mathrm{ND}$ & + & + & + & - \\
\hline
\end{tabular}


Table 2. Cellular fatty acid compositions (\%) of strain LLO4 12.1.7 ${ }^{\top}$ and the type strains of other Tenacibaculum species

Strains: 1, T. soleae sp. nov. LL04 $12.1 .7^{\mathrm{T}} ; 2$, T. mesophilum $\mathrm{MBIC} 1140^{\mathrm{T}} ; 3$, T. lutimaris $\mathrm{KCTC} 12302^{\mathrm{T}} ; 4$, T. skagerrakense ATCC BAA- $458^{\mathrm{T}}$; 5, T. maritimum NCIMB $2154^{\mathrm{T}}$; 6, T. litoreum JCM $13039^{\mathrm{T}} ; 7$, T. aestuarii KCTC $12569^{\mathrm{T}} ; 8$, T. litopenaei BCRC $17590^{\mathrm{T}}$. Data from Yoon et al. (2005), Jung et al. (2006), Choi et al. (2006), Sheu et al. (2007) and this study. -, Not detected; tr, trace $(<1 \%)$; ECL, equivalent chain-length. No data were available for $T$. ovolyticum, T. gallaicum or T. discolor. Fatty acids amounting to less than $1 \%$ of the total fatty acids in all strains tested are not listed.

\begin{tabular}{|c|c|c|c|c|c|c|c|c|}
\hline Fatty acid & 1 & 2 & 3 & 4 & 5 & 6 & 7 & 8 \\
\hline \multicolumn{9}{|l|}{ Straight chain } \\
\hline $\mathrm{C}_{15: 0}$ & 4.8 & 3.6 & 8.9 & 4.9 & 2.9 & 2.7 & 6.1 & - \\
\hline$C_{16: 0}$ & $\operatorname{tr}$ & $\operatorname{tr}$ & $\operatorname{tr}$ & $\operatorname{tr}$ & $\operatorname{tr}$ & $\operatorname{tr}$ & $\operatorname{tr}$ & 1.8 \\
\hline \multicolumn{9}{|l|}{ Branched chain } \\
\hline iso- $\mathrm{C}_{13: 0}$ & $\operatorname{tr}$ & $\operatorname{tr}$ & $\operatorname{tr}$ & $\operatorname{tr}$ & 1.8 & 1.4 & 1.3 & $\operatorname{tr}$ \\
\hline iso- $\mathrm{C}_{14: 0}$ & 2.4 & $\operatorname{tr}$ & 1.7 & $\operatorname{tr}$ & $\operatorname{tr}$ & 2.2 & 2.2 & $\operatorname{tr}$ \\
\hline iso- $\mathrm{C}_{15: 0}$ & 23.1 & 13.2 & 17.2 & 9.5 & 16.8 & 18.8 & 18.9 & 22.0 \\
\hline anteiso- $\mathrm{C}_{15: 0}$ & $\operatorname{tr}$ & 1.1 & $\operatorname{tr}$ & - & $\operatorname{tr}$ & 1.8 & 2.0 & $\operatorname{tr}$ \\
\hline iso- $\mathrm{C}_{15: 1}$ & 5.7 & 7.1 & 5.3 & 8.2 & 7.6 & 8.2 & 8.7 & 8.7 \\
\hline iso- $\mathrm{C}_{16: 0}$ & 1.7 & 1.7 & 3.8 & 1.3 & $\operatorname{tr}$ & 2.3 & 2.3 & 1.8 \\
\hline iso- $\mathrm{C}_{16: 1}$ & 2.4 & $\operatorname{tr}$ & 1.7 & 1.7 & - & 1.3 & $\operatorname{tr}$ & 1.6 \\
\hline iso- $\mathrm{C}_{17: 1} \omega 9 c$ & - & $\operatorname{tr}$ & $\operatorname{tr}$ & $\operatorname{tr}$ & - & 1.6 & 1.3 & 1.6 \\
\hline \multicolumn{9}{|l|}{ Unsaturated } \\
\hline $\mathrm{C}_{15: 1} \omega 6 c$ & 12.2 & 1.6 & 4.2 & - & 2.2 & 1.7 & 3.0 & 1.6 \\
\hline $\mathrm{C}_{17: 1} \omega 6 c$ & 1.7 & $\operatorname{tr}$ & 1.5 & 1.2 & $\operatorname{tr}$ & $\operatorname{tr}$ & 1.6 & 1.9 \\
\hline $\mathrm{C}_{18: 3} \omega 6 c$ & - & - & - & - & - & 1.5 & - & - \\
\hline \multicolumn{9}{|l|}{ Hydroxylated } \\
\hline iso- $\mathrm{C}_{15: 0} 3-\mathrm{OH}$ & 10.6 & 8.0 & 4.6 & 7.8 & 19.8 & 6.6 & 6.1 & 4.6 \\
\hline $\mathrm{C}_{15: 0} 2-\mathrm{OH}$ & $\operatorname{tr}$ & 1.1 & 1.2 & 2.5 & 1.1 & $\operatorname{tr}$ & $\operatorname{tr}$ & $\operatorname{tr}$ \\
\hline $\mathrm{C}_{15: 0} 3-\mathrm{OH}$ & 3.2 & 2.9 & 3.4 & 8.6 & 3.8 & - & 4.2 & 2.7 \\
\hline iso- $\mathrm{C}_{16: 0} 3-\mathrm{OH}$ & 8.4 & 9.0 & 12.8 & 12.2 & 5.0 & 6.8 & 12.3 & 3.4 \\
\hline $\mathrm{C}_{16: 0} 3-\mathrm{OH}$ & 2.2 & 3.2 & 1.3 & 2.1 & 1.5 & 1.6 & 1.0 & 5.4 \\
\hline iso- $\mathrm{C}_{17: 0} 3-\mathrm{OH}$ & 2.9 & 14.9 & 8.4 & 11.7 & 13.7 & 13.6 & 9.6 & 12.7 \\
\hline $\mathrm{C}_{17: 0} 3-\mathrm{OH}$ & - & $\operatorname{tr}$ & $\operatorname{tr}$ & 2.5 & - & $\operatorname{tr}$ & $\operatorname{tr}$ & 1.0 \\
\hline \multicolumn{9}{|c|}{ Unknown fatty acids } \\
\hline ECL 13.565 & $\operatorname{tr}$ & $\operatorname{tr}$ & - & - & - & - & - & 1.9 \\
\hline ECL 16.582 & $\operatorname{tr}$ & 1.0 & $\operatorname{tr}$ & $\operatorname{tr}$ & 1.0 & 1.0 & 1.0 & $\operatorname{tr}$ \\
\hline \multicolumn{9}{|l|}{ Summed features ${ }^{\star}$} \\
\hline Summed feature 3 & 11.0 & 24.4 & 18.1 & 22.5 & 17.9 & 19.6 & 11.9 & 21.3 \\
\hline Summed feature 4 & - & - & - & - & - & 1.3 & - & - \\
\hline
\end{tabular}

${ }^{*}$ Summed feature are groups of two or three fatty acids that cannot be separated by GLC using the MIDI system. Summed feature 3 comprises $\mathrm{C}_{16: 1} \omega 7 c$ and/or iso- $\mathrm{C}_{15: 0}$ 2-OH. Summed feature 4 comprises iso- $\mathrm{C}_{17: 1} \mathrm{I}$ and/or anteiso- $\mathrm{C}_{17: 1} \mathrm{H}$.

\section{Description of Tenacibaculum soleae sp. nov.}

Tenacibaculum soleae [so.le' ae. L. gen. n. soleae of a sole, in reference to the source of the isolate, a cultured sole (Solea senegalensis Kaup)].

Cells are Gram-negative rods, $0.5 \mu \mathrm{m}$ in diameter and 2$25 \mu \mathrm{m}$ in length, motile by gliding. Spherical cells are observed in ageing cultures. Colonies on FMM agar and MA 2216 (Difco) are flat and yellow with uneven edges and do not adhere to the agar. The yellow pigment does not belong to the flexirubin type. Strictly aerobic. Growth occurs in media containing 50-100\% seawater, but not in media supplemented with $\mathrm{NaCl}$ only. Growth occurs at 14$30{ }^{\circ} \mathrm{C}$ (optimum $22-25{ }^{\circ} \mathrm{C}$ ) and $\mathrm{pH}$ 6.0-8.0. Catalase and cytochrome oxidase activities are present. Gelatin and casein are hydrolysed, but Tween 80 and starch are not. The Voges-Proskauer test is negative. No acid is produced from carbohydrates. $\mathrm{H}_{2} \mathrm{~S}$ and indole are not produced. LProline, L-glutamate, sucrose, (-)-D-ribose, $(+)$-D-galactose, $(+)$-D-glucose and L-tyrosine are not utilized. In the API ZYM system, alkaline phosphatase, esterase, esterase lipase, lipase, leucine arylamidase, valine arylamidase and cystine arylamidase activities are present, but trypsin, $\alpha$ chymotrypsin and all enzymes related to the metabolism of carbohydrates are absent.

The type strain is LL04 $12.1 .7^{\mathrm{T}}\left(=\mathrm{CECT} 7292^{\mathrm{T}}=\mathrm{NCIMB}\right.$ $14368^{\mathrm{T}}$ ), isolated from a diseased sole (Solea senegalensis) reared in Galicia (north-western Spain).

\section{Acknowledgements}

This investigation was supported by grant PGIDIT 04 RMA 003E from the Xunta de Galicia, Spain. The authors acknowledge Stolt Sea Farm for the collaboration provided for the study, Dr J. P. Euzéby (Laboratoire de Bactériologie, École Nationale Vétérinaire, Toulouse, France) for his help with species names and Dr David Arahal (Colección Española de Cultivos Tipo, CECT, Burjassot, Valencia, Spain) for constructive suggestions.

\section{References}

Bernardet, J.-F., Segers, P., Vancanneyt, M., Berthe, F., Kersters, K. \& Vandamme, P. (1996). Cutting a Gordian knot: emended classification and description of the genus Flavobacterium, emended description of the family Flavobacteriaceae, and proposal of Flavobacterium hydatis nom. nov. (basonym, Cytophaga aquatilis Strohl and Tait 1978). Int J Syst Bacteriol 46, 128-148.

Bernardet, J.-F., Nakagawa, Y. \& Holmes, B. (2002). Proposed minimal standards for describing new taxa of the family Flavobacteriaceae and emended description of the family. Int J Syst Evol Microbiol 52, 1049-1070.

Buck, J. D. (1982). Non-staining ( $\mathrm{KOH})$ method for determination of gram reactions of marine bacteria. Appl Environ Microbiol 44, 992-993.

Choi, D. H., Kim, Y.-G., Hwang, C. Y., Yi, H., Chun, J. \& Cho, B. C. (2006). Tenacibaculum litoreum sp. nov., isolated from tidal flat sediment. Int J Syst Evol Microbiol 56, 635-640.

Chun, J., Lee, J.-H., Jung, Y., Kim, M., Kim, S., Kim, B. K. \& Lim, Y. W. (2007). EzTaxon: a web-based tool for the identification of prokaryotes based on $16 \mathrm{~S}$ ribosomal RNA gene sequences. Int J Syst Evol Microbiol 57, 2259-2261.

Cowan, S. T. \& Steel, K. J. (1965). Manual for the Identification of Medical Bacteria. London: Cambridge University Press.

Felsenstein, F. (2007). PHYLIP (phylogeny inference package) version 3.67. Distributed by the author. Department of Genome Sciences, University of Washington, Seattle, USA. 
Fitch, W. M. (1971). Toward defining the course of evolution: minimum change for a specific tree topology. Syst Zool 20, 406-416.

Frette, L., Jørgensen, N. O. G., Irming, H. \& Kroer, N. (2004). Tenacibaculum skagerrakense sp. nov., a marine bacterium isolated from the pelagic zone in Skagerrak, Denmark. Int J Syst Evol Microbiol 54, 519-524.

Hansen, G. H., Bergh, Ø., Michaelsen, J. \& Knappskog, D. (1992). Flexibacter ovolyticus sp. nov., a pathogen of eggs and larvae of Atlantic halibut, Hippoglossus hippoglossus L. Int J Syst Bacteriol 42, 451-458.

Jung, S.-Y., Oh, T.-K. \& Yoon, J.-H. (2006). Tenacibaculum aestuarii sp. nov., isolated from a tidal flat sediment in Korea. Int J Syst Evol Microbiol 56, 1577-1581.

Kimura, M. (1980). A simple model for estimating evolutionary rates of base substitutions through comparative studies of nucleotide sequences. J Mol Evol 16, 111-120.

Pazos, F., Santos, Y., Macías, A. R., Nuñez, S. \& Toranzo, A. E. (1996). Evaluation of media for the successful culture of Flexibacter maritimus. J Fish Dis 19, 193-197.

Piñeiro-Vidal, M., Riaza, A. \& Santos, Y. (2008). Tenacibaculum discolor sp. nov. and Tenacibaculum gallaicum sp. nov., isolated from sole (Solea senegalensis) and turbot (Psetta maxima) culture systems. Int J Syst Evol Microbiol 58, 21-25.

Reichenbach, H. (1989). Order I. Cytophagales Leadbetter 1974. In Bergey's Manual of Systematic Bacteriology, vol. 3, pp. 2011-2013. Edited by J. T. Staley, M. P. Bryant, N. Pfennig \& J. G. Holt. Baltimore: Williams \& Wilkins.

Reichenbach, H. (1992a). The order Cytophagales. In The Prokaryotes, 2nd edn, vol. 4, pp. 3631-3675. Edited by A. Balows, H. G. Trüper, M. Dworkin, W. Harder \& K. H. Schleifer. New York: Springer.

Reichenbach, H. (1992b). Flavobacteriaceae fam. nov. In Validation of the Publication of the New Names and New Combinations Previously
Effectively Published Outside the IJSB, List no. 41. Int J Syst Bacteriol 42, 327-329.

Saitou, N. \& Nei, M. (1987). The neighbor-joining method: a new method for reconstructing phylogenetic trees. Mol Biol Evol 4, 406-425.

Sasser, M. (1990). Identification of bacteria by gas chromatography of cellular fatty acids, MIDI Technical Note 101. Newark, DE: MIDI.

Sheu, S.-Y., Lin, K.-Y., Chou, J.-H., Chang, P.-S., Arun, A. B., Young, C.-C. \& Chen, W.-M. (2007). Tenacibaculum litopenaei sp. nov., isolated from a shrimp mariculture pond. Int J Syst Evol Microbiol 57, 1148-1153.

Stackebrandt, E. \& Ebers, J. (2006). Taxonomic parameters revisited: tarnished gold standards. Microbiol Today 33, 152-155.

Stackebrandt, E. \& Goebel, B. M. (1994). Taxonomic note: a place for DNA-DNA reassociation and 16S rRNA sequence analysis in the present species definition in bacteriology. Int J Syst Bacteriol 44, 846-849.

Suzuki, M., Nakagawa, Y., Harayama, S. \& Yamamoto, S. (2001). Phylogenetic analysis and taxonomic study of marine Cytophaga-like bacteria: proposal for Tenacibaculum gen. nov. with Tenacibaculum maritimum comb. nov. and Tenacibaculum ovolyticum comb. nov., and description of Tenacibaculum mesophilum. Int J Syst Evol Microbiol 51, 1639-1652.

Thompson, J. D., Higgins, D. G. \& Gibson, T. J. (1994). CLUSTAL W: improving the sensitivity of progressive multiple sequence alignment through sequence weighting, position-specific gap penalties and weight matrix choice. Nucleic Acids Res 22, 4673-4680.

Wakabayashi, H., Hikida, M. \& Masumura, K. (1986). Flexibacter maritimus sp. nov., a pathogen of marine fishes. Int J Syst Bacteriol 36, 396-398.

Yoon, J.-H., Kang, S.-J. \& Oh, T.-K. (2005). Tenacibaculum lutimaris sp. nov., isolated from a tidal flat in the Yellow Sea, Korea. Int J Syst Evol Microbiol 55, 793-798. 